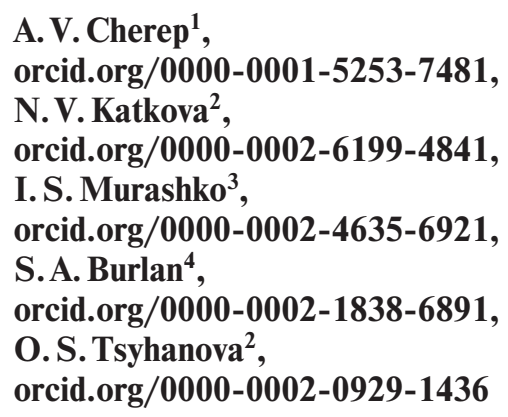

1 - Zaporizhzhia National University, Zaporizhzhia, Ukraine 2 - Admiral Makarov National University of Shipbuilding, Mykolaiv, Ukraine, e-mail: nataliavkatkova@gmail.com 3 - Danube branch of "Interregional Academy of Personnel Management", Izmail, Ukraine

4 - Petro Mohyla Black Sea National University, Mykolaiv, Ukraine

\title{
IDENTIFICATION AND ASSESSMENT THE FACTORS OF INFLUENCE ON THE FORMATION OF THE MACHINE-BUILDING ENTERPRISE SUSTAINABLE DEVELOPMENT MECHANISM
}

Purpose. To identify, systematize, classify and assess the factors of internal and external environment influencing the formation of a mechanism for the sustainable development of machine-building enterprises.

Methodology. To achieve this goal, a set of general scientific and special methods was used in the work: historical and logical generalization - to analyze existing approaches to the definition and classification of factors influencing enterprises' sustainable development; induction and deduction, system analysis, expert evaluation - to identify, evaluate and rank the stated factors.

Findings. A system of factors influencing the sustainability mechanism is generalized and expanded. External factors include economic, political, environmental, social, energy ones, as well as added factors of heredity. Among the internal factors, there are economic, environmental, social, energy ones, as well as added factors to counteract environmental disturbance, behavioral factors, size of enterprises, which take into account the peculiarities of functioning of the sustainable development mechanism. It is determined that among the environmental factors such factors as stability of political power, rate of economic growth, inflation rate, cost of energy resources, tax policy, restrictions on foreign trade, solvent demand, value of credit resources, availability of natural resources potential, profitability of industry production, bureaucratization and level of corruption, volume of fixed assets and circulating assets in the enterprises of the industry, probability of military conflicts, antitrust law are most influential. Among the internal ones these are personnel management, sufficient financial resources, profitability of production, availability of strategic planning system.

Originality. The classification of factors influencing the formation of the mechanism of machine-building enterprises' sustainable development has been further developed, including the factors of heredity and others, which take into account the peculiarities of functioning of the sustainable development mechanism in its relation to the environment.

Practical value. Taking into account the influence and priority of external and internal factors will allow forming an effective mechanism for sustainable development of specific machine-building enterprises.

Keywords: machine-building enterprises, sustainable development mechanism, external factors, internal factors

Introduction. In the conditions of further development of crisis facts in the economy and unpredictability of social processes dynamics, effective activity of machine-building enterprises and their ability to adapt are a key factor for ensuring the stability of functioning and formation of preconditions for sustainable development of Ukraine. Taking into account the fact that sustainable development of enterprises, on the one hand, ensures an increase in the efficiency of using all types of enterprise resources and the formation of new competitive advantages, and on the other hand, contributes to the harmonious coexistence of an enterprise with the external environment, an important and urgent task is to build an effective mechanism for sustainable development of machine-building enterprises. In turn, the peculiarities of the formation of the sustainable development mechanism of the enterprise are determined by the factors that influence it.

Literature review. Today, most scientists study mainly the factors that affect the enterprise's sustainable development, rather than its mechanism. However, regarding this issue among scientists there is no common view on the classification and assessment of their impact.

For example, O. P. Romanko, I.Z. Savchyn [1], studying the factors of sustainable economic development of enterprises, distinguish factors of external and internal environment. As for environmental factors, scientists, in turn, divide them into factors of direct and indirect action. O.V. Grinchenko [2] also proposes to divide the factors of sustainable development into two large

(C) Cherep A. V., Katkova N.V., Murashko I. S., Burlan S.A., Tsyhanova O.S., 2020 groups: internal and external. He notes that internal factors should be based on the definition and formation of an enterprise resource provision system. Factors of the internal environment can be effectively managed, and factors concerning the external environment can be used by the enterprise in the course of working out a development strategy and developing new markets.

Kyrych N. B., Melnyk L. M., Pohaidak O. B. [3] divide the factors of sustainable development into the following three groups: factors of the macroenvironment, mesoenvironment and microenvironment. The macroeconomic environment shows the dependence of sustainable development of the enterprise on economic, scientific and technical, political, legal, international, environmental and infrastructural factors. Factors of the mesoenvironment reflect the state of the industry as a whole, and also give an opportunity to estimate the peculiarities of influence of a condition of industry development on sustainable development of the separate enterprise related to it. Microenvironment factors operate from within the enterprise and, unlike the previous ones, they can be managed and, if necessary, make management decisions for their correction.

Ivanchenko V.I. and Koroliova A.A. [4] distinguish the following factors of the enterprise's sustainable development: financial stability and positive profitability dynamics; availability of customers, clients or consumers of products or services, i.e. sources of income of the enterprise; comfort of work, competence, social security in the staff - that is, factors that create a competitive advantages in the productivity of staff; the positive impact of the activity results on the public consciousness in terms of environmental protection and consumption of 
energy resources; positive assessment of the enterprise by society, staff and business partners.

Shandova N. V. summarizes the sustainable development factors of the enterprise into the following groups: factors that affect the social, economic and environmental components of sustainable development of the enterprise, as well as factors that determine the relationship between them. Halchak H. R. [5] divides the factors of sustainable development into internal and external, and distinguishes the following subgroups of factors in each group: economic, environmental, social, ethical and legal ones. Teleshevska S. M. offers a classification of sustainable development factors, which takes into account the economic performance of the enterprise, social and environmental components and a legal one Sikietina. N. G. [6] i distinguishes the stability of the external and internal environment $n$ the stability of the system. Factors of stability of the external environment include state-political, scientific-technical, economic, social, ecological ones. Factors of stability of the internal environment include factors of production, commercial, personnel, marketing, logistics.

Among the factors influencing the sustainable development of the enterprise, Barannik L. B. [7] pays special attention to tax policy. Bilan O. [8] identifies such a factor of sustainable development as corporate social responsibility. The company's social responsibility is understood as its activities under three types of responsibility: economic (quality and safety of products and services, their physical and price accessibility), environmental (reducing the level of harmful emissions and other loads on the environment) and social (investing in the development of the company's team, implementation of external social projects, and others).

Hrabovska I. V., considering the theoretical and practical aspects of the "sustainable development" concept, systematizes the factors of sustainable development of the enterprise, which include the following indicators: resource potential; volume and structure of products; level of production and technological potential; industry affiliation; production strategies; use of fixed and working capital; labor potential, and so on. Melnyk L. M., Maksimov I. E. [9], Hrabovska I. V. [10] distinguish the introduction of innovations among the factors of sustainable development.

Chepka V.V. and Matiash O.K. [11] distinguish such groups of factors of sustainable development as: factors of the first level (basic); second level (internal and external); third level (detailing); factors related to operating activity, investment and financial activities; economic, socio-political, financial, demographic factors, factors of scientific and technological progress; external (international, national, market) and internal (qualitative, quantitative); by place of origin, by the scale of influence, by structure, by the possibility of forecasting, by the importance of the result, by the degree of influence on the enterprise activity, by time, by the probability of realization.

Veregun A. M., Tarasenko I. O. [12] classify the factors of sustainable development into three groups: environmental, socio-ecological, conditions that determine the possibility of sustainable development (assessment of potential and creation of conditions necessary for the implementation of sustainable development strategy). Kindrat O. V. [13] identifies the following main factors that affect the enterprises' activities and, accordingly, the sustainability of their financial and economic condition: increase in prices for energy resources (objective increase in cost and a corresponding decrease in product competitiveness); exchange rate fluctuations, which leads to unforeseen expenses in economic activity; declining demand for products due to the economic crisis; tax pressure.

Thus, the scientists distinguish such criteria for the classification of external factors as economic and financial, social, energy, political and legal ones, factors of scientific and technological progress. Classification criteria such as infrastructure, trade union influence, sectoral, international are also given. Among the main criteria for classifying the internal factors of sustainable development, researchers distinguish social (personnel), economic and financial, environmental ones. There are also such classification criteria as technical-technological, managerial, marketing, product parameters, resource, energy, public consciousness, legal (ethical-legal), production, commercial, logistics, innovation, by type of activity (operational, investment and financial). Summarizing the views of researchers and examining the system of factors identified by scientists, influencing the sustainable development of the enterprise, we believe that they also have a direct impact on the formation of the mechanism of sustainable development. However, it is not exhaustive and needs to be expanded.

Purpose. The purpose of the article is to identify, systematize, classify and assess the factors of internal and external environment influence on the formation of the mechanism of machine-building enterprises' sustainable development.

Methods. To achieve this goal, a set of general scientific and special methods was used in the work: historical and logical generalization - to analyze existing approaches to the definition and classification of factors influencing enterprises' sustainable development; induction and deduction, system analysis, expert evaluation - to identify, evaluate and rank the factors that influence the formation of the mechanism of machine-building enterprises' sustainable development, as well as a graphic method - to visualize the article material.

Results. The bionomic approach to the formation of the mechanism of sustainable development determines the study of factors influencing the growth and development of the enterprise as a living organism [14]. So, external factors that affect the living organism are divided into heredity factors and environmental factors. Environmental factors determine the intensity of the functioning of certain structures of the body and the relationships between them. The existence and stability of living systems is ensured by the continuous exchange of substances and energy with the environment. The stability of living beings is always in dynamics, the immutability of living forms would lead to their disappearance. Accordingly, the sustainable development of enterprises will also always be in dynamics depending on changes in the external environment. Ideally, sustainable development of the country's economy can be achieved in the transition to the evolutionary sustainable development of all enterprises: newly created enterprises inherit the achievements of sustainable development of existing enterprises, and enterprise systems that have detected their inability to sustainable development are discarded.

Enterprises' environment factors are all external factors that influence the formation of the mechanism of enterprises' sustainable development: political, economic, environmental, social, energy, and others. So, having summarized and systematized the views of scientists, such external factors of influence on the formation of the mechanism of sustainable development of enterprises as political, environmental, economic, social, energy, and so on, were identified. And also, the factors of heredity were added: national, mental, cultural and other traditions of doing business, which have developed in society (Fig. 1).

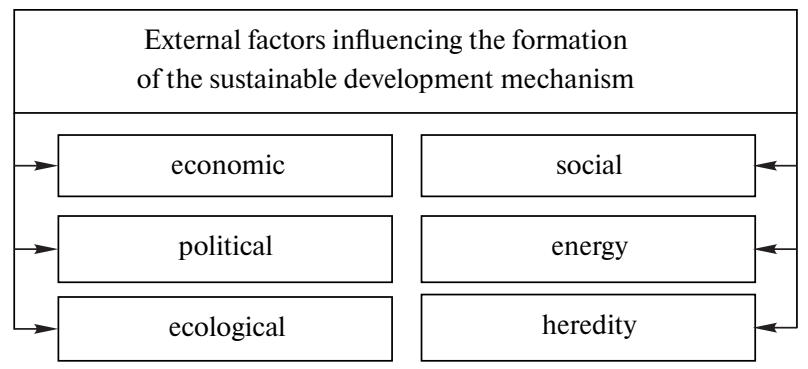

Fig. 1. Groups of external factors in fluencing the formation of the sustainable development mechanism of enterprises [1-15] 
External factors of influence on the formation of a sustainable development mechanism, which primarily affect the economic subsystem of an enterprise, include: restrictions on foreign trade, economic growth rate, inflation rate, exchange rates, infrastructure development, the volume of fixed and current assets in the industry, profitability of industry production, cost of credit resources, effective demand, tax policy, degree of intellectual property protection, level of innovation and technological development of the industry, level of fundamental and scientific and practical research, state programs to attract investment, degree of protectionism, cost of research and development, degree of globalization and economic openness, antitrust laws.

In particular, the factor of restrictions on foreign trade may lead to a contraction of markets; economic growth rates affect the revival of the market, which in turn contributes to the growth of sales volumes; high inflation leads to the devaluation of the company's assets; exchange rate fluctuations have a significant impact on businesses dealing with external counterparties and may result in exchange rate losses. The low level of infrastructure development causes additional costs for obtaining services related to the activities of the enterprise; the volume of fixed and current assets and profitability of production in the industry indicates the attractiveness of activities in this industry and the potential of the enterprise. The cost of credit resources is associated with the possibility of additional financial resources; effective demand affects sales; the level of tax pressure on the enterprise and, accordingly, the amount of taxes paid by enterprises depends on the tax policy. The degree of protection of intellectual property indicates the interest of enterprises in development and the possibility of earning income from them; the level of innovation and technological development of the industry contributes to increasing this level in the enterprise; the level of basic and scientific-practical research indicates the possibility of introducing innovations into production. State investment attraction programs affect the ability to attract financing for enterprises; the degree of protectionism affects the size of markets; research and development costs indicate the possibility and interest of enterprises in them; the degree of globalization and openness of the economy contribute to the possibility of entering new markets, gaining foreign experience; antitrust law promotes the development of small and medium-sized businesses, as well as restrains the influence of large enterprises on the market.

Political factors have a significant impact on the formation of the mechanism of sustainable development, in particular, the influence of the state on the sustainable development strategy lies in the fact that due to the popularization of ideas of sustainable development in society, the demand for various types of products is changing. The probability of military conflicts affects the size of markets, the possibility of functioning of certain divisions of the enterprise, raw material markets, the possibility of attracting investments, and so on. Bureaucratization and the level of corruption determine the simplicity and fairness of doing business, and can cause additional expenses; the stability of political power affects the ability to attract investment, changes in legislation, including tax and foreign economic; freedom of information and independence of the media ensure openness of activities.

External environmental factors affect the formation of the sustainable development mechanism through changes in demand for environmental products, the requirements of society and legislation, and so on. In particular, the attitude towards natural and ecological products forms the demand for them, which affects the production and sales volumes; the state and world standards of ecological policy determine the necessary production technology at the enterprise; the level of ecological education in the society affects the public opinion and attitude towards the enterprises-producers, as well as the opportunity to promote ecological products in a particular market; the environmental protection legislation forms the list of norms re- garding the possible pressure of the enterprise on the environment.

Social factors influence the formation of the sustainable development mechanism through human resources. Namely, the level of health care determines the degree of labor protection at the enterprise; attitude to work, vacation, and retirement determines the peculiarities of labor organization. The level of unemployment and the level of migration affect the volume of labor resources and the wage rate, the prestige of the industry creates attractive conditions for employment, the level of education while the availability of specialists determines the ability to form a staff of highly qualified workers; labor legislation, the amount and conditions of wages determine the costs of remuneration of labor.

Energy factors have an impact through the ability of the enterprise to attract energy resources (access to energy-saving and the latest technologies and the provision of the country's natural resource potential), and the amount of expenses for the resource acquisition (the cost of energy resources).

Factors of heredity affect through national, mental, cultural and other business traditions established in the society.

The system of internal factors influencing the formation of the mechanism of sustainable development of the enterprise includes the following (Fig. 2): economic, environmental, social, energy ones and they need to be expanded with such as the ability to counteract environmental disturbances, behavioral factors, and the size of the enterprise. In particular, in our opinion, an important internal factor is the size of the enterprise: large enterprises are able to resist the challenges of the external environment more strongly than small and medium ones, because they have large economic, labor, environmental and energy resources. Small and medium-sized enterprises occupy a certain market share that large enterprises cannot reach, they are more mobile.

Other factors that ensure the efficiency of the mechanism's operation include organizational and management communications, information processing and transmission technologies, organizational management structure, management decision support systems, and management methods.

Internal economic factors affect the formation of a mechanism for sustainable development through the possibility of increasing production through the production of quality products (availability of a quality management system), production technology and implementation of innovations (implementation of innovations, the degree of depreciation of fixed assets, cooperation with research and educational institutions ), efficient logistics, as well as through the possibility of financing of the enterprise activities (sufficiency of financial resources), including their own funds, which depends on the enterprise's cost effectiveness and its profitability.

Internal environmental factors influence the formation of the mechanism of sustainable development through technology and personnel of the enterprise. In particular, the avail-

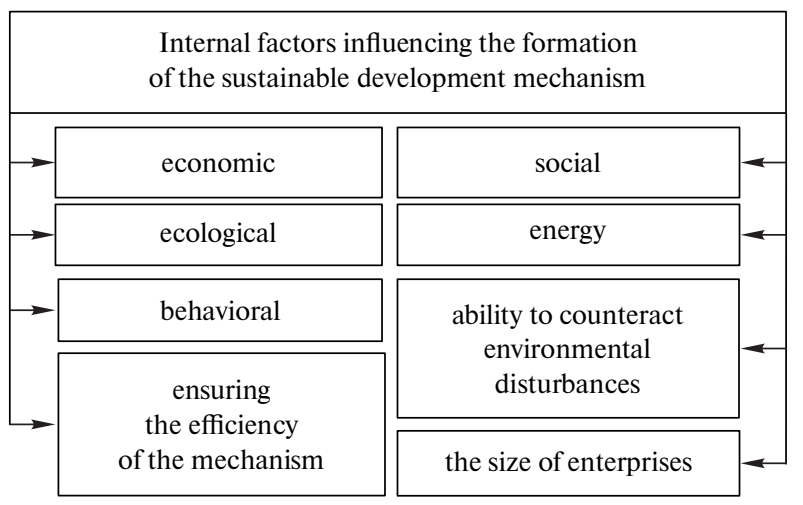

Fig. 2. Internal factors influencing the formation of the sustainable development mechanism [1-15] 
ability of an integral system of preservation and reproduction of the environment, the consciousness of staff and the implementation of environmental protection measures determine the degree of impact of the enterprise on the environment.

The formation of a sustainable development mechanism depends on social factors, including the efficiency of use of the company's personnel. In particular, HR management influences the efficiency of personnel selection, adaptation, transfer and promotion, and the like; infrastructure is related to the welfare of employees, the degree of their satisfaction with work at the enterprise; an effective motivation system contributes to an increase in labor productivity and employee satisfaction. The involvement of personnel in the general strategy of the enterprise determines the understanding of each employee of their tasks and functions in achieving the general goals of the companies, which also contributes to the growth of labor productivity and the degree of employee satisfaction. Effective organization of labor protection provides safe working conditions, which, on the one hand, affects employee satisfaction, and on the other - the company's image; organizational culture affects the effectiveness of relationships between employees and the degree of employee satisfaction. Effective work organization reduces the loss of working time and increases productivity; the level of education and qualification of work determines the ability to work productively; the level of wages, on the one hand, affects the costs of the enterprise, and on the other - productivity and employee satisfaction.

Internal energy factors affect the formation of the sustainable development mechanism through technologies and personnel of the enterprise, in particular, technologies, availability of own energy sources, implementation of energy saving measures, energy cost planning, complex processing of raw materials and production waste.

The factor of ability to counteract the environmental disturbance involves the development of subsystems of sustainable development of the enterprise, which is influenced by the competence of employees in the field of sustainable development, the involvement of employees in the mechanism of sustainable development, the willingness of management personnel to resist the challenges of the external environment.

By behavioral factors, enterprises, like living beings, can be "predators" or "herbivores". Enterprises with aggressive development - "predators" - are enterprises that aim to expand markets, their own growth, and so on, and at the same time are able to absorb market shares or smaller enterprises. "Herbivorous" enterprises are enterprises with non-aggressive development. The role of "herbivorous" enterprises in economic development is to transform the environment by processing input resources (information, raw materials, etc.) into finished products or services. The role of "predators" in the economy, as well as in wildlife, extends also to "orderlies", since they are capable of absorbing or displacing weak, uncompetitive enterprises from the market. According to the chosen strategy of sustainable development (aggressive or non-aggressive), enterprises react differently to the challenges of the external environment.

The factor of the size of an enterprise determines its financial stability, the ability to attract resources, and the like. Ensuring the functioning of the mechanism is related with the debugging of organizational and managerial ties, technology for processing and transmitting information, the organizational structure of management, support systems for making managerial decisions, management methods.

In order to assess the degree of influence of these factors on the formation of the sustainable development mechanism of machine-building enterprises, a survey was conducted among 73 experts. Specialists of various profiles working at machine-building enterprises, managers of different levels, as well as scientists were selected as experts.

In the questionnaire, experts were asked to assess 36 external factors and 35 internal factors from 1 to 10 points in terms of the degree of impact. The external factor, which, according to the expert, has the greatest influence on the formation of the sustainable development mechanism, is assigned a larger number of points -10 points, a factor with less influence 9 points, and the factor that has the least influence -1 point. Further, by summing up, the total number of points that each factor received from all experts is determined, and the total number of points received by all indicators is also determined. The weighting factor of each factor is defined as the ratio of the number of points of a particular factor to the total number of points.

According to the results of the study, the following factors have the greatest influence on the formation of the sustainable development mechanism of enterprises (Fig. 3): stability of political power $(0.037)$, rate of economic growth $(0.037)$, inflation rate (0.036), cost of energy resources $(0.036)$, tax policy $(0.036)$, restrictions on foreign trade $(0.036)$, effective demand $(0.035)$, cost of credit resources $(0.033)$, provision of the country's natural resource potential $(0.033)$, profitability of the industry (0.033).

The following factors also have a great influence: bureaucratization and the level of corruption (0.032), the volume of fixed and current assets of enterprises in the industry $(0.31)$, the probability of military conflicts $(0.031)$, antitrust law (0.030). The influence of such external factors as the level of education and availability of specialists (0.029), development of market, transport and innovation infrastructure (0.027), environmental legislation (0.027), the level of environmental culture in society (0.027), labor legislation (0.026), the state's influence on the strategy of sustainable development $(0.026)$, access to energysaving and latest technologies $(0.26)$, the prestige of the industry for employment $(0.026)$ is also significant.

Factors with a significant impact also include the degree of globalization and openness of the economy $(0.025), \mathrm{R} \& \mathrm{D}$ expenditures $(0.024)$, the degree of protectionism $(0.024)$, heredity $(0.024)$, government investment programs $(0.023)$, exchange rates $(0.023)$, migration level $(0.023)$, unemployment rate $(0.022)$, degree of intellectual property protection $(0.021)$, society's attitude to natural and ecological products $(0.021)$, level of basic and scientific-practical research (0.021).

The least influential are the following factors with a weighting factor of 0.20, namely: the level of health care, the level of innovation and technological development of the industry, freedom of information and media independence.

Similarly to the external factors, the internal factors were ranked (Fig. 4).

The greatest influence on the formation of a sustainable development mechanism with a weighting factor of 0.034 is exerted by such factors as personnel management, adequacy of financial resources, profitability of production, and the presence of a strategic planning system.

The following internal factors also have a significant impact: the presence of a cost management system (0.33), the size of enterprises $(0.032)$, information processing and transmission technology (0.032), implementation of innovation $(0.32)$, the level of education and skills $(0.31)$, organizational and managerial relations $(0.031)$, the degree of depreciation of fixed assets (0.031), effective labor organization $(0.30)$, organizational management structure $(0.030)$, the use of energysaving technologies $(0.30)$, the level of wages $(0,30)$, development of enterprise infrastructure (0.30), level of education and labor qualification.

Factors such as efficient logistics (0.029), involvement of personnel in the general strategy of the company (0.029), effective system of labor protection at the enterprise (0.029), energy cost planning (0.027), availability of quality management system (0.027) have an average impact. Medium-impact factors also include behavioral factors $(0.027)$, complex processing of raw materials and use of industrial waste (0.026), ability to counteract external disturbances $(0.026)$, effective motivation system (0.026), management decision support systems 


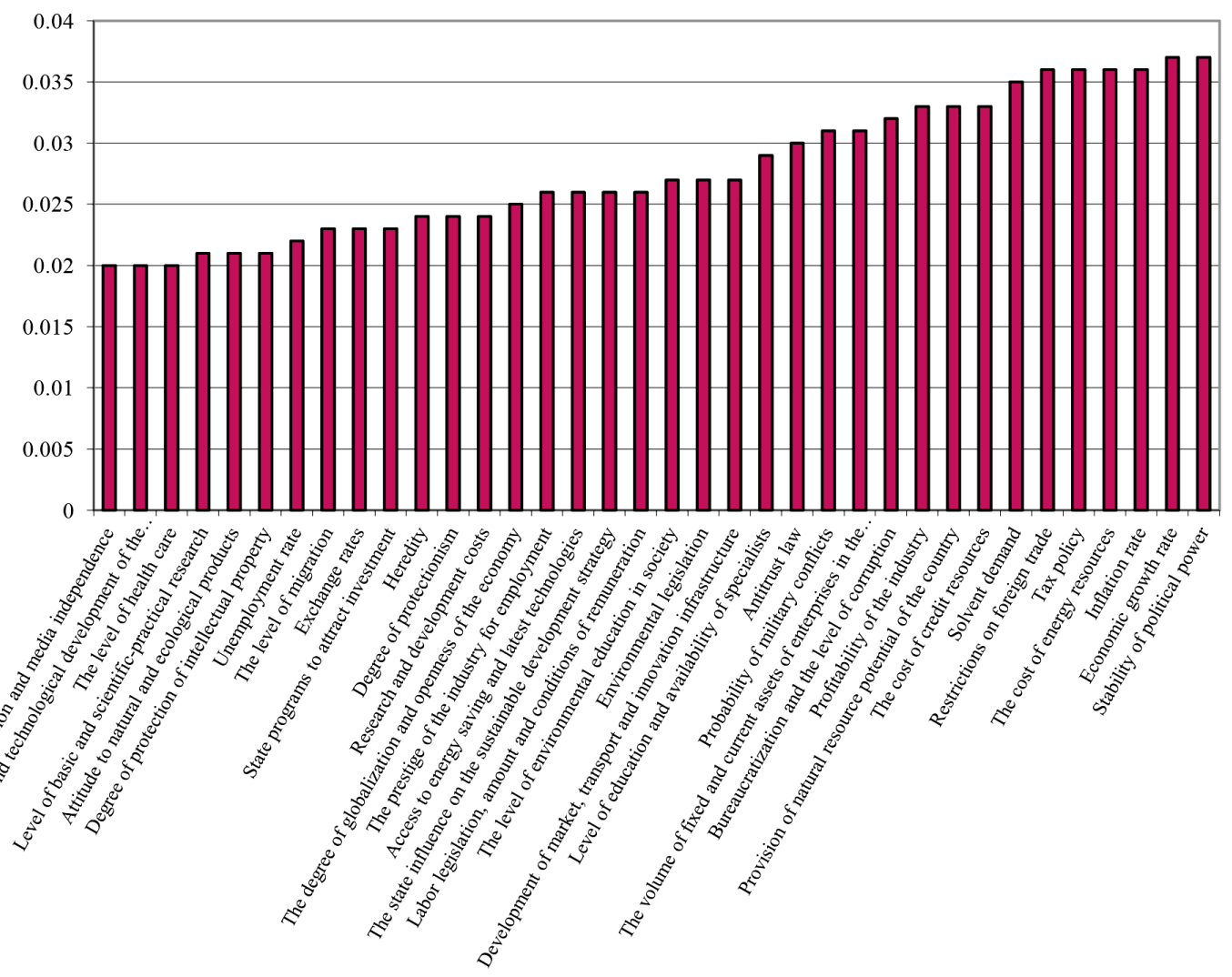

Fig. 3. Ranking of external factors influencing the formation of the sustainable development mechanism of machine-building enterprises

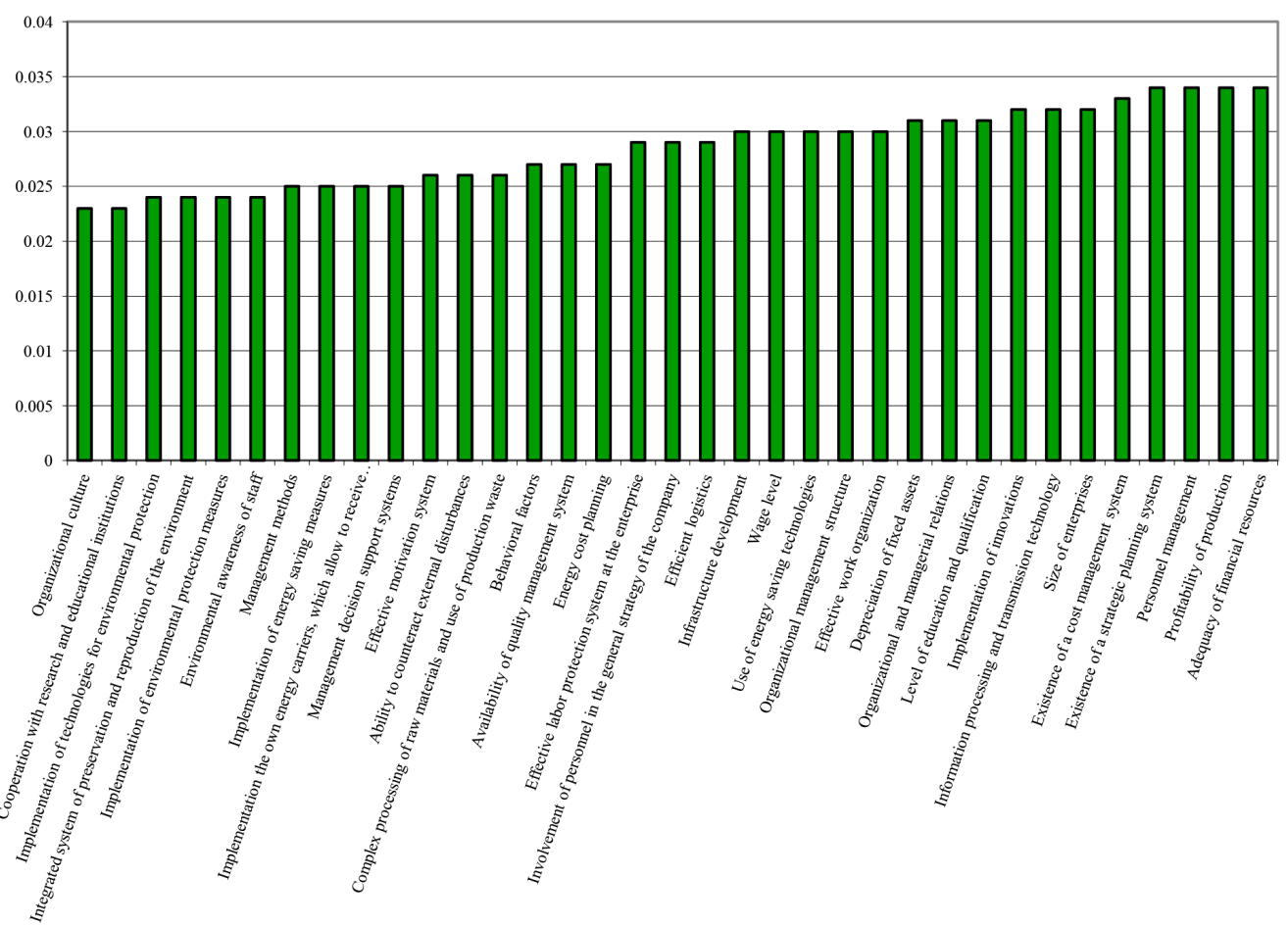

Fig. 4. Ranking of internal factors influencing the formation of the sustainable development mechanism of the machine-building enterprises

(0.025), implementation of modern resource-saving technologies (0.025), implementation of energy saving measures (0.025), management methods $(0.025)$.

Factors such as environmental awareness of staff (0.024), implementation of environmental protection measures (0.024), integrated environmental protection and reproduc- tion system (0.024), implementation of environmental protection technologies (0.024), cooperation with research and educational institutions $(0.023)$, organizational culture $(0.023)$ have the least impact.

Influence of factors consists in formation of an enterprise's existence environment, creation of the barriers which restrain 
excessive influence of the enterprises on environment. External factors of sustainable development of enterprises are external disturbances that cause compensatory facts in the internal environment of the enterprise. Any environmental factor that has reached certain intensity will affect the enterprise. This factor will cause a number of changes in various subsystems of sustainable development of the enterprise.

Conclusions. The study and generalization of the scientists views on the factors system of influence on the formation of the sustainable development mechanism and our own practical research made it possible to single out economic, political, environmental, social, energy factors among the external factors of influence, and also to add factors of heredity that determine the influence of national, mental, cultural and other traditions of doing business that have developed in society.

Among the internal factors the following are singled out: economic, ecological, social, energy ones, as well as added factors of ability to counteract environmental disturbances (competence of workers in sustainable development, inclusion of workers in the sustainable development mechanism), behavioral factors (aggressive or non-aggressive development of enterprises), the size of enterprises and ensuring the effectiveness of the mechanism (organizational and managerial relations, management methods, information processing and transmission technologies, decision support systems, organizational management structure), which take into account the peculiarities of the functioning of the sustainable development mechanism in its interconnection with the external environment.

According to the evaluation and ranking of factors, it was determined that among the external factors the most influential are factors such as the stability of political power, economic growth, inflation, energy costs, tax policy, restrictions on foreign trade, effective demand, cost of credit, provision of natural resource potential of the country, profitability of the industry, bureaucratization and the level of corruption, the amount of fixed and current assets of enterprises in the industry, the probability of military conflicts, antitrust law; and among the internal ones - personnel management, adequacy of financial resources, profitability of production, existence of strategic planning system.

Acknowledgements. The study was carried out in accordance with the general research topic of the work of the PJSC "Higher Educational Institution "Interregional Academy of Personnel Management": "Problems and prospects for the development of industrial and agricultural enterprises in Ukraine" (state registration number 0117U00024).

\section{References.}

1. Romanko, O. P., \& Savchyn, I.Z. (2015). Internal and external environment of influence on the economic stability of oil and gas enterprises. Global and national economic problems, 8, 598-602.

2. Grinchenko, O. V. (2017). Factors of effective development of enterprises of fruit and vegetable complex. Young scientist, 6(46), 406-410.

3. Kyrych, N. B., Melnyk, L. M., \& Pohaidak, O. B. (2015). Sustainable development of business entities: the essence and factors of influence (European accents). Bulletin of Economic Science of Ukraine, 2, 151-155.

4. Ivanchenko, V. O., \& Koroliova, A. A. (2015). Ecological and resource component of sustainable development of Ukrainian enterprises. Scientific notes, 17, 47-50.

5. Halchak, H. R. (2016). Ensuring sustainable development of the enterprise as a basis for the formation of social responsibility. Bulletin of Lviv Polytechnic National University, 847, 69-74. 6. Sikietina, N.G. (2017). Factors for sustainable development of the enterprise. Information technologies: science, technic, technology, education, health: proceedings of the XXV International scientific-practical conference MicroCAD-2017, May 1719, Part III, (pp. 261-262). Retrieved from http://pim.net.ua/ arch f/tez mic 17 III.pdf.
7. Barannik, L. B. (2016). Factors of financial support of sustainable development of enterprises: tax aspect. Scientific notes of the National University "Ostroh Academy". "Economy" series, 3(31), 86-91. Retrieved from http://nbuv.gov.ua/UJRN/ Nznuoa_2016 3 _ 18.

8. Bilan, O. (2016). Corporate social responsibility as a factor of sustainable development of enterprises in the region. $R e-$ gional aspects of the development of productive forces, 21, 40-46. 9. Melnyk, L. M., \& Maksimov, I. E. (2017). Implementation of innovations as a factor in ensuring sustainable development of industrial enterprises. Actual problems of modern technologies: proceedings of International scientific and technical conference of young scientists and students (Ternopil, November 16-17), 3, 196. Retrieved from http://elartu.tntu.edu.ua/bitstream/ lib/23165/2/CAZST_2017v3_Melnyk_L_M-Implementation of innovations 196.pdf.

10. Hrabovska, I. V. (2019). The role of innovation in ensuring the competitiveness and sustainable development of industrial enterprises. Bulletin of Khmelnytskyi National University, 4, 1217.

11. Chepka, V.V., \& Matiash, O. K. (2017). Financial stability of the enterprise: essence and factors of influence. Economy and society, 12, 649-655.

12. Veregun, A. M., \& Tarasenko, I. O. (2014). The concept of sustainable development in the context of globalization. Bulletin of KNUTD. Problems of economics of organizations and management of enterprises, 2, 207-217.

13. Kindrat, O. V. (2017). Estimation of influence of factors of internal and external environments on stability of a financial and economic condition of the enterprises. Actual problems of economics, 1, 140-149.

14. Murashko, I. S. (2017). Bionomic approach to sustainable development of the enterprise. Bulletin of Zaporizhzhia $\mathrm{Na}$ tional University, 4(36), 43-49.

\section{Ідентифікація та оцінка факторів впливу на формування механізму стійкого розвитку підприємства машинобудування}

\author{
A. В. Череп ${ }^{1}$, Н. В. Каткова ${ }^{2}$, I. С. Мурашко ${ }^{3}$, \\ С.А. Бурлан ${ }^{4}$, О. С. Циганова ${ }^{2}$
}

1 - Запорізький національний університет, м. Запоріжжя, Україна

2 - Національний університет кораблебудування імені адмірала Макарова, м. Миколаїв, Україна, е-mail: nataliavkatkova@gmail.com

3 - Придунайська філія ПрАТ «Міжрегіональна Академія управління персоналом», м. Ізмаїл, Україна

4 - Чорноморський національний університет імені Петра Могили, м. Миколаїв, Україна

Мета. Ідентифікація, систематизація, класифікація та оцінка факторів впливу внутрішнього й зовнішнього середовища на формування механізму стійкого розвитку підприємств машинобудування.

Методика. Для досягнення визначеної мети в роботі використано комплекс загальнонаукових і спеціальних методів: історичного й логічного узагальнення - для аналізу існуючих підходів до визначення та класифікації факторів впливу на стійкий розвиток підприємств; індукції та дедукції, системного аналізу, експертних оцінок - для ідентифікації, оцінки й ранжування наведених факторів.

Результати. Узагальнена й розширена система факторів, шо впливають на механізм стійкого розвитку. Серед зовнішніх факторів впливу виокремлені економічні, політичні, екологічні, соціальні, енергетичні, а також додані фактори спадковості. Серед внутрішніх факторів відмічені економічні, екологічні, соціальні, енергетичні, а 
також додані фактори здатності протидіяти збурюванням зовнішнього середовища, поведінкові фактори, розміри підприємств, що враховують особливості функціонування механізму стійкого розвитку. Визначено, що серед факторів зовнішнього середовища найбільший вплив чинять: стійкість політичної влади, темп зростання економіки, рівень інфляції, вартість енергетичних ресурсів, податкова політика, обмеження на зовнішню торгівлю, платоспроможний попит, вартість кредитних ресурсів, забезпеченість природно-ресурсним потенціалом, рентабельність виробництва галузі, бюрократизація й рівень корупції, обсяг основних засобів і обігових активів у підприємств галузі, ймовірність військових конфліктів, антимонопольне законодавство. Серед внутрішніх: кадровий менеджмент, достатність фінансових ресурсів, рентабельність виробництва, наявність системи стратегічного планування.

Наукова новизна. Набула подальшого розвитку класифікація факторів впливу на формування механізму стійкого розвитку підприємств машинобудування, зокрема, виокремлені фактори спадковості та інші, що враховують особливості функціонування механізму стійкого розвитку в його взаємозв 'язку із зовнішнім середовищем.

Практична значимість. Полягає в тому, що врахування впливу та пріоритетності зовнішніх і внутрішніх факторів дозволить сформувати дієвий механізм стійкого розвитку конкретних підприємств машинобудування.

Ключові слова: підприємства машинобудування, механізм стійкого розвитку, зовнішні фактори, внутрішні фактори

\section{Идентификация и оценка факторов влияния на формирование механизма устойчивого развития предприятия машиностроения}

\author{
А. В. Череп ${ }^{1}$, Н. В. Каткова ${ }^{2}$, И. С. Мурашко ${ }^{3}$, \\ С. А. Бурлан ${ }^{4}$, А. С. Цыганова 2
}

1 - Запорожский национальный университет, г. Запорожье, Украина

2 - Национальный университет кораблестроения имени адмирала Макарова, г. Николаев, Украина, е-mail: nataliavkatkova@gmail.com

3 - Придунайский филиал ЧАО «Межрегиональная Академия управления персоналом», г. Измаил, Украина 4 - Черноморский национальный университет имени Петра Могилы, г. Николаев, Украина

Цель. Идентификация, систематизация, классификация и оценка факторов внутренней и внешней среды, влияющих на формирование механизма устойчивого развития предприятий машиностроения.

Методика. Для достижения поставленной цели в работе использован комплекс общенаучных и специальных методов: исторического и логического обобщения - для анализа существующих подходов к определению и классификации факторов влияния на устойчивое развитие предприятий; индукции и дедукции, системного анализа, экспертных оценок - для идентификации, оценки и ранжирования указанных факторов.

Результаты. Обобщена и расширена система факторов, влияющих на механизм устойчивого развития. Среди внешних факторов выделены экономические, политические, экологические, социальные, энергетические, а также добавлены факторы наследственности. Среди внутренних факторов отмечены экономические, экологические, социальные, энергетические, а также добавлены факторы способности противодействия возмущениям внешней среды, поведенческие факторы, размеры предприятий, которые учитывают особенности функционирования механизма устойчивого развития. Определено, что среди факторов внешней среды наибольшее влияние оказывают: устойчивость политической власти, темп роста экономики, уровень инфляции, стоимость энергетических ресурсов, налоговая политика, ограничения на внешнюю торговлю, платежеспособный спрос, стоимость кредитных ресурсов, обеспеченность природно-ресурсным потенциалом, рентабельность производства отрасли, бюрократизация и уровень коррупции, объем основных средств и оборотных активов у предприятий отрасли, вероятность военных конфликтов, антимонопольное законодательство. Среди внутренних: кадровый менеджмент, достаточность финансовых ресурсов, рентабельность производства, наличие системы стратегического планирования.

Научная новизна. Получила дальнейшее развитие классификация факторов, влияющих на формирование механизма устойчивого развития предприятий машиностроения, в частности, выделены факторы наследственности и другие, которые учитывают особенности функционирования механизма устойчивого развития в его взаимосвязи с внешней средой.

Практическая значимость. Заключается в том, что учет влияния и приоритетности внешних и внутренних факторов позволит сформировать действенный механизм устойчивого развития конкретных предприятий машиностроения.

Ключевые слова: предприятия машиностроения, механизм устойчивого развития, внешние факторы, внутренние факторы

Recommended for publication by H. K. Rohov, Doctor of Economic Sciences. The manuscript was submitted 23.04.20. 